\title{
PENDIDIKAN MULTIKULTURAL
}

\author{
Thamrin Tayeb
}

Fakultas Tarbiyah \& Keguruan

UIN Alauddin Makassar

\begin{abstract}
Multicultural education can be described as education that awakens learners to cultural diversity, human rights or the reduction of various kinds of prejudices in building a just and prosperous society. This modeling education, trying to see how family roles awaken individuals in the family, that cultural diversity must be acceptable to every individual family. This education, an alternative solution for learners who do not want to work together, just because of differences in culture, ethnicity, and beliefs. Ideal education strengthens the sense of brotherhood in various differences.
\end{abstract}

Keywords: Multicultural Education, Cultural Diversity, Family.

\section{PENDAHULUAN}

$\mathrm{I}$ stilah pendidikan dewasa ini telah banyak mengalami perkembangan, baik secara teoritis ataupun praktis, berbagai macam percobaan serta penelitian telah banyak melahirkan ratusan filosof pendidikan yang hasilnya dijadikan dasar atau landasan operasional pendidikan di lapangan. Berbagai persoalan sering kali menjadi penghambat atau penghalang pertumbuhan pendidikan baik di daerah, pusat bahkan hingga pendidikan dunia. Persoalan yang dihadapi hanya berkisar pada perbedaan budaya, etnik, dan keyakinan.

Misalnya saja mengapa pendidikan keluarga sangat fundamental dalam membentuk peserta didik menjadi individu yang dapat mengerti keragaman?

Di sisi lain, mungkin perlu kita mengetahui bahwa dalam masyarakat dunia pendidikan, ternyata bahwa tidak semua individu dapat mengerti dan mau bekerja sama hanya karena perbedayaan budaya, etnik, dan keyakinan. Mungkin yang tak kalah pentingnya adalah bagaimana pendidikan yang ideal dapat memperkuat rasa persaudaraan walau terdapat perbedaan. Selanjutnya penulis akan kemukakan permasalahan berikut.

Dalam tulisan ini, penulis akan menguraikan beberapa hal yang yang ada kaitanya dengan pendidikan Multikultural diantaranya;

1. Mengapa pendidikan keluarga sangat fundamental membentuk anak-anak menjadi individu-individu yang dapat mengerti keragaman budaya dalam masyarakat?

2. Mengapa dalam masyarakat dunia pendidikan, tidak semua individu dapat mengerti dan mau bekerja sama, karena perpedaan budaya, etnik, dan keyakinan? 
3. Bagaimana pendidikan yang ideal dapat memperkuat rasa persaudaraan walaupun terdapat banyak perbedaan?

\section{A. Peranan Keluarga dalam Lingkungan Sosial dan Hukum}

Ada dua macam kaidah yang mengatur kehidupan pribadi dan kehidupan antar pribadi yaitu kaidah kepercayaan dan kaidah kesusilaan disatu sisi, dan kaidah kesopanan dan kaidah hukum di sisi yang lain.

Kaidah yang mengatur kehidupan pribadi adalah kaidah kepercayaan dan kaidah kesusilaan. Kaidah kepercayaan bertujuan kepada antar manusia penganut kehidupan beriman, sedang kaidah kesusilaan bertujuan agar manusia mempunyai hati nurani yang bersih.

Kaidah yang mengatur kehidupan antar pribadi adalah kaidah kesopanan dan kaidah hukum. Kaidah kesopanan bertujuan untuk melancarkan pergaulan hidup, sedang kaidah hukum bertujuan untuk mencapai kedamaian (Soekanto, 2009:22).

\section{Keluarga}

Pembicaraan mengenai keluarga akan dibatasi pada keluarga batih. Keluarga batih terdiri dari suami/ayah, istri/ibu dan anak-anak yang belum menikah. Pada umumnya keluarga batih ini merupakan unit pergaulan hidup yang terkecil dalam masyarakat. Di samping keluarga batih, kita juga mengenal unit-unit pergaulan lain seperti keluarga luas (extended family), komunitas (community) dan sebagainya.

Menurut Soekanto (2009) bahwa keluarga batih mempunyai peran-peran utama sebagai berikut:

a. Sebagai pelindung bagi pribadi-pribadi yang menjadi anggota, dan memperoleh ketenteraman dan ketertiban dalam keluarga.

b. Unit-ekonomis yang secara materil dapat memenuhi kebutuhan anggotanya.

c. Membangun dan menumbuhkan kaidah-kaidah pergaulan hidup bagi anggotanya.

d. Sebagai wadah manusia mengalami proses sosialisasi awal, dalam mematuhi kaidah-kaidah dan nilai-nilai yang berlaku di dalam masyarakat.

Dari peranan keluarga batih tersebut, nyatalah betapa pentingnya keluarga bagi perkembangan kepribadian seseorang. Gangguan pada pertumbuhan kepribadian seseorang mungkin disebabkan pecahnya kehidupan keluarga batih secara fisik maupun mental.

Di Indonesia, peranan keluarga semakin penting, terutama di kota-kota besar bahkan sampai ke desa-desa. Selanjutnya Soekanto (2009) menyatakan bahwa meningkatnya peranan keluarga batih disebabkan oleh faktor-faktor sebagai berikut:

a. Hubungan darah yang kuat, kemudian diikuti oleh hubungan karena tempat tinggal yang sama.

b. Pembagian kerja dalam masyarakat yang semakin berkembang ke arah keterampilan individual, menyebabkan kemampuan individual lebih diutamakan daripada kemampuan kolektif. 
c. Pusat kehidupan yang semula berada di kelompok-kelompok kekerabatan semakin beralih ke keluarga batih.

d. Penerapan program Keluarga Berencana yang menekankan pada pengaturan kehamilan dan pembatasan kelahiran, mengakibatkan semakin eratnya hubungan antar anggota keluarga batik.

Dengan demikian, maka peranan orang tua dalam keluarga batih akan semakin penting bagi anak-anaknya, dalam upaya persiapan mematuhi kaidah-kaidah/nilai-nilai yang ada berlaku di dalam masyarakat.

\section{Keluarga batih dan lingkungan}

Secara sosiologi, lingkungan sosial mencakup lingkup yang sangat luas oleh karena berdasarkan pada interaksi sosial. Peranan lingkungan sosial di Indonesia, tampaknya masih besar apabila dibandingkan dengan peranan keluarga batih, terutama pada lapisan menengah dan bawah. Bahkan dapat dikatakan, bahwa faktor-faktor eksternal lebih besar perannya dalam pembentukan kepripadian seseorang. Hal ini tidak saja berkaitan dengan pola hidup spiritual, akan tetapi juga aspek materinya. Lingkungan sosial tersebut secara sederhana dapat dibedakan antara lingkungan pendidikan formal, lingkungan pekerjaan, dan lingkungan tetangga (Soekanto, 2009:25).

Tampaknya lingkungan pendidikan formal mempengaruhi pola hidup anak-anak yang sekolah. Lingkungan pekerjaan sangat mempengaruhi pola hidup orang tua. Selanjutnya lingkungan tentangga banyak mempengaruhi keluarga batih lapisan-lapisan menengah dan bawah, sedang pada lapisan atas tampaknya pola hidup keluarga batih lebih banyak dipengaruhi oleh faktor-faktor intern, sehingga peranan keluarga batih lebih menonjol.

Keluarga batih lapisan atas, telah banyak dominan berpengaruh atas perkembangan anak-anak mereka, karena lebih terdidik, penguasaan pengetahuan yang lebih konprehensif, dan pengalaman-pengalaman sukses yang banyak telah banyak diraih (Soekanto, 2009:26).

\section{Lingkungan Hukum}

Pada kehidupan keluarga yang lebih menekankan pada segi spiritual, lingkungan hukum pada umumnya mengikuti perkembangan pola hidup dan mengesankan gejala yang terjadi. Lingkungan hukum mencakup antara lain, perundang-undangan, hukum adat, hukum yuri-prudensi (putusan-putusan hakim), traktat (perjanjian-perjanjian internasional) dan hukum yang dihasilkan oleh kalangan intelektual hukum (Soekanto, 2009:26).

Perlu diketahui bahwa perundang-undangan yang berkaitan dengan kehidupan keluarga, lebih banyak dianut oleh masyarakat perkotaan. Sedang hukum adat lebih banyak dianut oleh masyarakat pedesaan. 
Oleh karena itu, makin majemuk suatu masyarakat, maka kebutuhan terhadap keluarga semakin besar, ketergantungan seseorang akan keluarga akan semakin penting, sehingga peran orang tua terhadap anak-anaknya akan menonjol.

Demikian pula, pemahaman anak-anak sebagai individu terhadap keragaman budaya dalam masyarakat akan semakin jelas, semuanya adalah peranan orang tua sebagai nakhoda keluarga batik.

\section{B. Jenis Kontak Sosial: Keluarga, Sekolah dan Masyarakat}

Jenis kontak sosial anak didik terdiri dari tiga macam, yakni: kontak sosial di keluarga, sekolah dan masyarakat (Idi, 2011:91).

Kontak sosial pertama adalah di keluarga. Keluarga yang terdiri dari ayah dan ibu dan anak, masing-masing saling mempengaruhi, saling membutuhkan, semua meladeni seseorang, dan seseorang meladeni semua. Anak membutuhkan makanan, pakaian, bimbingan, dan sebagainya dari orang tua dan orang tua membutuhkan rasa bahagia dengan kelahiran anak (Idi, 2011:91).

Selama anak belum dewasa, orang tua mempunyai peran utama bagi anakanaknya. Untuk membawa anak kepada kedewasaan, orang tua harus memberi contoh yang baik, karena anak suka mengimitasi kepada orang tuanya. Dalam memberikan sugesti kepada anak diharapkan tidak menggunakan cara otoriter, melainkan dengan sistem pergaulan sehingga dengan senang akan melaksanakannya. Anak paling suka untuk identik dengan tuanya, seperti anak laki-laki terhadap ayahnya dan anak perempuan terhadap ibunya.

Kontak sosial kedua adalah di sekolah. Sekolah sebagai lembaga pendidikan formal, terdiri dari guru dan murid. Antara mereka sudah barang tentu terjadi adanya saling hubungan, baik antara guru/pendidik dengan murid, maupun antara murid dengan murid. Guru sebagai pendidik, dengan wibawanya dalam pergaulan membawa murid sebagai anak didik ke arah kedewasaan. Memanfaatkan pergaulan sehari-hari dalam pendidikan adalah cara yang paling baik dan efektif dalam pembentukan pribadi dan dengan cara ini pula maka hilanglah jurang pemisah antara guru dan murid (Idi, 2011:91).

Kontak sosial antara murid dengan murid juga menunjukkan suasana edukatif. Sesama murid saling berkawan, berolahraga bersama dengan ketentuan-ketentuan yang berlaku, saling mengajak dan diajak, saling berceritera, saling berdisiplin diri agar tidak menyinggung perasaan temannya.

Kontak sosial ketiga adalah di masyarakat. Masyarakat merupakan tempat pergaulan sesama manusia dan merupakan lapangan pendidikan yang luas dan meluas, yaitu adanya hubungan antara dua orang atau lebih tak terbatas. Idi (2011) menegaskan bahwa pendidikan itu secara mutlak merupakan tujuan yang mencakup sesuatu nilai yang tertinggi, mencakup nilai kesusilaan, mencakup nilai yang membimbing anak dalam menunaikan tugas hidupnya, mencakup nilai kerohanian pada anak melalui 
kontak sosial. M.J. Langeveld (t.t) mengatakan bahwa pendidikan adalah usaha dari pihak orang dewasa untuk membantu mendewasakan anak-anak yang belum dewasa. Ngalim Purwanto (1985) mendefinisikan bahwa pendidikan adalah segala usaha orang dewasa dalam pergaulannya dengan anak-anak untuk memimpin perkembangan jasmani dan rohaninya ke arah kedewasaan.

Selanjutnya Idi (2011) menyatakan dalam bukunya bahwa agar proses pendidikan dapat berjalan dengan baik dan lancar, maka seorang pendidik mempunyai ciri pertama yaitu memiliki wibawa atau kewibawaan. Kewibawaan yaitu pengaruh positif normatif yang diberikan kepada orang lain atau anak didik dengan tujuan agar yang bersangkutan dapat mengembangkan dirinya seoptimal mungkin. Pendidik adalah orang tua kedua setelah orang tuannya sendiri, karena berfungsi sebagai pendidik, maka di dalam melaksanakan tugasnya ia seorang yang harus profesional.

Ciri kedua, yaitu pendidik harus mengenal secara pribadi anak/peserta didik yang secara otomatis hafal nama asuhannya. Ciri ketiga, yaitu pendidik harus mau membantu peserta didik dalam arti peserta didik terus-menerus dibantu. Peserta didik adalah "aku" yang berkepribadian dan ingin bertanggung jawab dan ingin menentukan diri sendiri. Dalam memahami proses kontak sosial di sekolah, sangat ditentukan oleh peranan pendidik, di mana hal ini merupakan harapan bagi orang tua peserta didik. Untuk menimbulkan kontak sosial edukatif bagi peserta didik, seorang pendidik memiliki peranan penting dalam proses perwujudannya, seperti halnya peran elemen warga sekolah lainnya yakni orang tua, stat administrasi, penjaga sekolah, dan lain sebagainya, tidak kalah pula perannya dalam menciptakan para peserta didik yang dapat memiliki suatu kondisi kontrak sosial yang edukatif di sekolah. Hal ini, dikarenakan sekolah merupakan suatu sistem, sehingga kontak sosial yang edukatif tergantung pada bagaimana kondisi kinerja sistem sekolah.

Berdasarkan apa yang penulis kemukakan di atas, maka untuk kondisi sosial kita sekarang, maka sangat tergantung kepada kondisi lapisan masyarakat dimana kita berada, apakah berada di lapis bawah, menengah atau di lapis atas. Namun demikian, penulis ingin mengatakan bahwa berdasarkan uraian dikemukakan terdahulu, bahwa keluarga yang berada pada lapis atas, menunjukkan bahwa orang tua memiliki peran yang sangat besar terhadap anak-anaknya untuk mau bekerja sama sunggupun mereka harus berbeda budaya, etnik dan keyakinan. Hal ini karena orang tua dapat menjadi tauladan, dengan wawasan keilmuan yang lebih kompleks, hidup yang lebih mapan, pergaulan yang lebih bervariasi dari budaya, etnik dan keyakinan.

\section{Sosialisasi Peserta Didik}

Proses sosial pada masyarakat pada dasarnya akan mengarahkan juga pada masalah proses sosialisasi pada usia anak. Hal ini cukup beralasan karena anak merupakan bagian dari masyarakat dan sebagai objek penting dalam proses sosialisasi. Sebagai bagian dari masyarakat, anak dituntut dapat hidup bermasyarakat secara baik, 
dan sebagai proses sosialisasi, anak merupakan individu yang perlu mendapatkan proses belajar bermasyarakat. Anak sebagai objek penting dalam proses pembelajaran mempunyai kedudukan penting dalam proses sosialisasi (Idi, 2011:104). Sebagai fungsi sosial, selain fungsi biologis, ekonomis dan agama, keluarga memiliki peran sangat krusial dalam proses sosialisasi. Orang tua hendaknya memberi tauladan yang baik bagi anak-anaknya tentang banyak hal dalam konteks proses sosialisasi. Sosialisasi anak diharapkan sebagai bekal ke depan agar anak beradaptasi dan berkiprah secara positif di tengah masyarakat (Idi, 2011:105).

Selanjutnya bersosialisasi pada pendidikan formal di sekolah di mana mereka menuntut ilmu pengetahuan. Setelah masuk sekolah, anak diharapkan dapat menyesuaikan diri dengan kondisi serta aturan-aturan sekolah yang berlaku. Di sekolah anak berinteraksi dengan pendidikan, staf karyawan, teman sejawat. Anak di sekolah memperoleh pendidikan formal berupa nilai-nilai, pengetahuan, keterampilan dan sikap terhadap mata pelajaran. Dari proses sosialisasi di sekolah anak akan membentuk kepribadian untuk tekun dan rajin belajar, memiliki cita-cita, dan lain-lain (Idi, 2011:105).

Selanjutnya Idi (2011) mengatakan bahwa di masyarakat, anak mendapatkan pendidikan berupa pengalaman hidup. Setiap masyarakat menurunkan kebudayaannya kepada generasi penerus melalui interaksi sosial. Interaksi sosial yang berjalan dengan baik berarti proses sosialisasi terjadi dengan baik. Lingkungan sekitar tempat tinggal anak sangat mempengaruhi perkembangan pribadi anak. Di situlah anak memperoleh pengalaman bergaul dengan teman-temannya di luar rumah dan sekolah yang memberikan pengaruh sosial pertama kepada si anak di luar keluarga. Dalam lingkungan masyarakat, anak akan mempelajari hal-hal yang baik, sebaliknya anak juga dapat mempelajari hal-hal yang buruk. Di sinilah peran seluruh anggota masyarakat menjadi sangat penting.

Berdasarkan uraian penulis di atas, bahwa peran orang tua, pendidikan dan tokoh masyarakat sangat penting dalam meletakkan rasa persaudaraan peserta didik walau berbeda budaya, etnik dan keyakinan.

\section{KESIMPULAN}

1. Pemahaman anak-anak sebagai individu terhadap keragaman budaya dalam masyarakat akan semakin jelas semuanya, karena peranan orang tua sebagai nakhoda keluarga batik.

2. Keluarga yang berada pada lapis atas, menunjukkan bahwa orang tua memiliki peran yang sangat besar terhadap anak-anaknya untuk mau bekerja sama, sungguhpun mereka harus berbeda budaya, etnik dan keyakinan. Hal ini karena orang tua dapat menjadi tauladan, dengan wawasan keilmuan yang lebih kompleks, hidup yang lebih mapan, pergaulan yang lebih bervariasi dari budaya, etnik dan keyakinan. 
3. Peran orang tua, pendidikan dan tokoh masyarakat sangat penting dalam meletakkan rasa persaudaraan peserta didik walau berbeda budaya, etnik dan keyakinan.

\section{DAFTAR PUSTAKA}

Damsar.2011. Pengantar Sosiologi Pendidikan. Jakarta: Kencana.

Idi, A. 2011.Sosiologi Pendidikan: Individu, Masyarakat, dan Pendidikan. Jakarta: Rajawali Press

Mahfud, C. 2011. Pendidikan Multikultural. Yogyakarta: Pustaka Pelajar.

Soekanto, S. 2009. Sosiologi Keluarga: Tentang Ikhwal Keluarga, Remaja dan Anak. Jakarta: PT. Rineka Cipta. 